\section{Correspondence on 'Increased risk of systemic lupus erythematosus in patients with autoimmune haemolytic anaemia'}

With great interest, we read the recent article by Mo et al regarding the association between autoimmune haemolytic anaemia (AIHA) and the subsequent development of systemic lupus erythematosus (SLE) based on a nationwide populationbased cohort. ${ }^{1}$ In this study, the authors found that patients with AIHA had an increased risk of SLE (HR 54.67; 95\% CI 22.33-133.89). We appreciate Mo et al's work on this group of patients with a high risk of developing SLE, which should be more carefully managed in the future, however, we would like to address some points.

First, previous studies have indicated that patients with childhood-onset SLE were more likely to have AIHA compared with adulthood-onset ones. ${ }^{2}{ }^{3}$ Therefore, we suggest that the authors should describe the incidence of AIHA in different age populations, which is interesting and may be clinically valued.

Second, the haematological system is often involved in SLE, which may manifest as one or more lineages of haemocytopenia. Thrombocytopenia was reported to be independently associated with the severity of AIHA in patients with SLE. ${ }^{4}$ Zhu et al in their retrospective study based on the same population cohort even demonstrated that the patients with idiopathic thrombocytopenic purpura (ITP) had a 26-times higher risk of new-onset SLE compared with the control population. ${ }^{5}$ Therefore, we suggest that the authors should investigate the difference in the incidence of SLE between patients with both AIHA and ITP and those with either AIHA or ITP. Besides, it has been proposed that both AIHA and autoimmune thrombocytopenia are associated with antiphospholipid antibodies, suggesting the presence of antibodies against the epitopes on the red cell membrane and platelets, probably the shared mechanisms in their pathophysiology. ${ }^{67}$ Therefore, the laboratory data of antiphospholipid antibodies will be of interest and probably important.

Finally, we noted that the HRs were extremely high with a wide range of $95 \%$ CI values (eg, 95\% CI 91.15-235.84) in the study. Based on a nationwide population cohort study, all the patients with AIHA were identified by searching the International Classification of Diseases, Ninth Revision (ICD-9) code, which would inevitably lead to selection bias. Some patients presenting with AIHA may have been in the early stage of SLE, however actually included in the AIHA group in the study. The authors should at least check the autoantibodies to make sure the diagnosis of AIHA. Furthermore, the low incidence rates of SLE in the non-AIHA control group as well as insufficient consideration of risk factors strongly related to developing SLE in the database may also have contributed to the bias. ${ }^{8}$ Time-varying effect analysis to show the adjusted HR in different time intervals from AIHA to SLE diagnosis may be helpful.
Hong Huang $\odot$, Zhuoli Zhang $\odot$

Department of Rheumatology and Clinical Immunology, Peking University First Hospital, Beijing, China

Correspondence to Professor Zhuoli Zhang, Department of Rheumatology and Clinical Immunology, Peking University First Hospital, Beijing 100034, China; zhuoli.zhang@126.com

Contributors $\mathrm{HH}$ wrote the paper. ZZ reviewed and edited the manuscript. Both authors read and approved the manuscript.

Funding The authors have not declared a specific grant for this research from any funding agency in the public, commercial or not-for-profit sectors.

Competing interests None declared.

Patient and public involvement Patients and/or the public were not involved in the design, or conduct, or reporting, or dissemination plans of this research.

Patient consent for publication Not required.

Provenance and peer review Not commissioned; internally peer reviewed.

(C) Author(s) (or their employer(s)) 2020. No commercial re-use. See rights and permissions. Published by BMJ.

\section{Check for updates}

To cite Huang H, Zhang Z. Ann Rheum Dis Epub ahead of print: [please include Day Month Year]. doi:10.1136/annrheumdis-2020-219257

Received 7 October 2020

Accepted 9 October 2020

\section{Glinked}

- http://dx.doi.org/10.1136/annrheumdis-2020-219269

Ann Rheum Dis 2020;0:1. doi:10.1136/annrheumdis-2020-219257

ORCID iDs

Hong Huang http://orcid.org/0000-0002-1468-1586

Zhuoli Zhang http://orcid.org/0000-0001-7219-9141

\section{REFERENCES}

$1 \mathrm{Mo} \mathrm{H}-\mathrm{Y}$, Wei JCC, Chen X-H, et al. Increased risk of systemic lupus erythematosus in patients with autoimmune haemolytic anaemia: a nationwide population-based cohort study. Ann Rheum Dis 2020. doi:10.1136/annrheumdis-2020-218886. [Epub ahead of print: 22 Sep 2020].

2 Bundhun PK, Kumari A, Huang F. Differences in clinical features observed between childhood-onset versus adult-onset systemic lupus erythematosus: a systematic review and meta-analysis. Medicine 2017:96:e8086.

3 Artim-Esen B, Şahin S, Çene E, et al. Comparison of disease characteristics, organ damage, and survival in patients with juvenile-onset and adult-onset systemic lupus erythematosus in a combined cohort from 2 tertiary centers in turkey. J Rheumatol 2017:44:619-25.

4 Durán S, Apte M, Alarcón GS, et al. Features associated with, and the impact of hemolytic anemia in patients with systemic lupus erythematosus: $L X$, results from a multiethnic cohort. Arthritis Rheum 2008;59:1332-40.

5 Zhu F-X, Huang J-Y, Ye Z, et al. Risk of systemic lupus erythematosus in patients with idiopathic thrombocytopenic purpura: a population-based cohort study. Ann Rheum Dis 2020;79:793-9.

6 Sultan SM, Begum S, Isenberg DA. Prevalence, patterns of disease and outcome in patients with systemic lupus erythematosus who develop severe haematological problems. Rheumatology 2003:42:230-4.

7 Kokori SI, loannidis JP, Voulgarelis M, et al. Autoimmune hemolytic anemia in patients with systemic lupus erythematosus. Am J Med 2000;108:198-204.

8 Chua MHY, Ng IAT, W L-Cheung M, et al. Association between cigarette smoking and systemic lupus erythematosus: an updated multivariate Bayesian Metaanalysis. J Rheumatol 2020:47:1514-21. 